\title{
Plate Device
}

National Cancer Institute

\section{Source}

National Cancer Institute. Plate Device. NCI Thesaurus. Code C50106.

A sheet of metal or wood or glass or plastic. 